\title{
グルーピング過程を含む鋼構造物の対話型部材断面決定法 INTERACTIVE SECTION DETERMINATION METHOD OF STEEL STRUCTURES WITH MEMBER GROUPING PROCESSES
}

\author{
藤井英二*，荒木慶一**，上谷宏二*** \\ Eiji FUJII, Yoshikazu ARAKI and Koji UETANI
}

\begin{abstract}
Firstly, a nonlinear optimization problem is formulated taking only representative dimensions of steel sections as independent design variables. The other dimensions are determined using proportions, prepared from a list of standard profiles, to the design variables. In the optimization, the members are divided into groups having identical sectional dimensions. Then a method is presented for re-grouping of members to further reduce the optimal cost once obtained for a given set of groups. An indicator is proposed to estimate the probable reduction to be brought by splitting a group. Using the indicator, the group and the split that likely bring the most effective reduction are identified. Finally, a flowchart for structural design support system with the above automatic grouping is proposed. This system also contains interactive processes enabling the structural engineer to modify the grouping for a synthetically better design. Examples are shown to verify the validity of the indicator and to demonstrate the advantages of the support system.
\end{abstract}

Keywords : Section optimization, Grouping, Standard profiles, Structural design navigation system 断面最適化，グルーピング，規格断面，構造設計ナビゲーションシステム

\section{1. 序論}

建築物の構造設計には安全性やコストだけでなく，建築計画・設 備計画との調和，製作性・施工性，さらには美観・創造性等，実に 多様な要素を複合的に考慮することが求められる。それらの中には 論理化や数量化が困難なものもあり，しかも互いに深い関連性をも つことが多いので，対象の限定や理想化を伴う最適設計手法がその まま構造設計者の役割を代行することはできない。一方, 現在の構 造設計には, 部材断面の選定過程に代表されるように単純な試行錯 誤の繰り返しによってより良い解を探索する過程も多くある。部材 断面の選定過程では通常, ある断面を仮定して構造システムの変形 や応力を求め, コストを含む各種性能を評価することを繰り返して, 目標性能を満足する断面を探索する。繰り返しの回数や最終的に到 達する性能は構造設計者の経験や力量によって少なからず変わるも のの，基本的にこれは試行錯誤による探索過程である。つまり，最 適設計手法が効果を発揮しやすい分野と言えるが，構造設計の実務 ではほとんど用いられていない。

最適設計手法が断面決定にすら用いられない理由については多く の指摘がなされており, その内の幾つかについては解決法も提案さ れている。鋼構造における代表的な例として, 断面寸法もしくは断 面性能等の設計変数が通常は断面リストに示された特定の離散值を
とるため，連続変数最適化による結果を直接用いることはできない という問題がある。これについては，断面リストの特徴を反映した 連続変数で断面を表現した上で連続変数最適化を適用する手法 ${ }^{1) ~ 3) ~}$ や，遺伝的アルゴリズム $(\mathrm{GA})$ 等に基づく離散変数最適化手法 ${ }^{4)}$ が提 案されている。また, 鋼材重量最小化等の単一目的最適化では構造 設計上考慮すべき多様な要素が無視されることとなり，得られる解 が実用性の低いものになりがちだという問題もある。これについて は，鋼材重量以外の実用上重要な要素を目的関数や制約条件に採り 入れる手法 ${ }^{5)}$ 8)の他, 多目的最適化によって複数の目的関数間の卜 レードオフ関係を構造設計者に提示して意志決定を支援する手法 9) も提案されている。また，上谷は，構造設計者とコンピュータが逐 次情報をやり取りし, 制約条件や目標性能を更新しながら, より望 ましい方向に設計を誘導していく「構造設計ナビゲーションシステ ム」という概念 10 ), 11)を提唱している。この中で，ある固定された条 件下で望ましい解を探索する際には, 最適設計手法が部分的に利用 される。

このように，構造設計における最適設計手法の実用化の素地は 徐々に構築されてきていると言えるが，これまであまり論じられて いない重要な要素に部材のグルーピング, つまり, 同一の断面をと る部材集合を決定する過程がある。構造設計の実務では，接合部や
* 株式会社竹中工務店 工修

**京都大学大学院工学研究科建築学専攻 准教授. 博士 (工学)

*** 京都大学大学院工学研究科建築学専攻 教授·工博
Takenaka Corporation, M. Eng.

Assoc. Prof., Dept. of Architecture and Architectural Engineering, Graduate School of Engineering, Kyoto Univ., Dr. Eng.

Prof., Dept. of Architecture and Architectural Engineering, Graduate School of Engineering, Kyoto Univ., Dr. Eng. 
仕上げ材との取り合いの標準化を考え, できるだけ多くの部材を同 一断面にしたいという要求がある。一方, すべての部材を同一断面 とすると, 部材によってその断面性能の利用効率のばらつきが大き くなり, 不経済な設計となってしまう。現状では両者のバランスを とるのも構造設計者の役割の一つとなっているが, これは繰り返し 探索過程である上に一回の探索の中に断面寸法の決定という下位の 繰り返し探索過程が含まれるため, 到達性能はおのずと構造設計に 許される時間という制約の影響を受けやすい。

既往の最適設計手法では部材グルーピングは与条件として取り扱 われることが多いが, 適切なグルーピングを見出すことを目的とし た手法も幾つか提案されている。例えば Krishnamoorthy et al. ${ }^{12}$ やTogan and Daloglu ${ }^{13}$ は, 予備解析で得た軸力等に応じてトラス 部材をグルーピングした上で, GA を用いて断面最適化を行ってい る。しかしながら, いずれもグルーピングの際に目的関数值が考慮 されないという問題がある。また, グループ数は予め規定されてお り，それが解に与える影響を調べるには最適化を繰り返す必要があ る。Wallsa and Elvin ${ }^{14}$ は, 全部材の断面を独立として断面最適化 を行った後に, 最適断面積の順に並べた部材リストを規定数のグル ープに分割し，あらためて最適化を実行する手法を提案している。 部材リストを分割する際には, あるグループ内のすべての部材断面 をそのグループ内の最大断面積のものに揃えるという条件の下で, 目的関数值が最小となるような分割位置が総当たりによって探索さ れる。しかしながら, 最初の断面最適化で全部材断面を設計変数と する必要があることを考えると大規模構造物への適用は困難である。

本論では, 最適設計手法を用いた鋼構造物の部材断面決定問題を 対象とし, 性能の高い解を効率的に得るための部材グルーピング手 法を提案する。本論で扱う最適化問題は, せい・幅等の代表的断面 寸法を連続設計変数とし, 応力や变位等に関する制約条件の下で部 材コストを最小化する断面最適化問題である。まず, 任意の方法で 部材を幾つかのグループに分類し, グループ内の部材は同一断面を とるとして最適解を求める。次に, 部材コストをさらに低減させる ために, グループの一つを分割する手法を提案する。最も効果的な 分割パターンを見出すために, 分割後の再最適化によって低減され るコストを簡便に近似予測する方法を提案する。また, 目的関数や 制約関数として採り入れることはしないが実務上は無視し切れない 重要な要素を反映して実用的な設計解を得るために, 構造設計者に よるグルーピングの修正操作を含めた対話型の設計支援システムを 提案する。部材グルーピングに論理的な評価指標を与え, さらには 構造設計者との情報のやり取りを通して最終的な設計解に到達する 本論の手法は, 構造設計ナビゲーションシステムの基礎的形態の一 つと位置づけられる。

\section{2. 断面最適化問題の定式化}

節点位置や部材配置, 支持条件, 荷重条件が与えられた鋼構造物 を考える。部材は $n_{S}$ 個のグループに分類され, グループ $i$ に属する 部材番号の集合を $S_{i}$ とする。部材グルーピングは $\boldsymbol{S}=\left\{S_{i}\right\}\left(i=1,2, \cdots, n_{S}\right)$ で定義され，本章ではこれを与条件とする。 すべての部材 $j \in S_{i}$ は材質を含めて同一の断面とし, 例えばその断 面寸法を $S_{i}$ の断面寸法と呼ぶ。ここで, 次の断面最適化問題を定式 化する。

\section{断面最適化問題}

応力・変位等に関する制約条件の下で総部材コストを最小化す るような, 各部材グループの断面寸法を求めよ。すなわち,

find $\boldsymbol{x}=\left\{\boldsymbol{x}_{i}\right\}$

to minimize $P(\boldsymbol{x})=\sum_{i} \beta_{i}\left\{\sum_{j \in S_{i}} w_{j}(\boldsymbol{x})\right\}$

subject to

$g(x) \geq 0, h(x)=0$

$\boldsymbol{x}=\left\{\boldsymbol{x}_{\boldsymbol{i}}\right\}$ は全設計変数, $\boldsymbol{x}_{\boldsymbol{i}}$ は特に $S_{i}$ に関する設計変数(独立な断面寸 法)を表す心゙クトルである。 $\beta_{i}$ は $S_{i}$ の質量単価, $w_{j}(\boldsymbol{x})$ は部材 $j$ の質 量であり, 目的関数 $P(\boldsymbol{x})$ は総部材コストを表す。 $\boldsymbol{g}(\boldsymbol{x}), \boldsymbol{h}(\boldsymbol{x})$ は制約 関数べクトルである。以下では, 問題設定について補足する。

\section{1. 設計変数}

部材断面を設計変数とする場合, 規格断面リス卜内の番号といっ た離散的表現や，断面性能もしくは断面寸法といった連続的表現が 用いられることが多い。本論では, 断面形状の直感的把握や求解の 効率を考え, 断面寸法を連続変数として最適化を行い, 後に最適解 に近い規格断面を選択する。このときすべての寸法パラメータを設 計変数に選ぶと, 寸法の組が不定または不定に近い状況になり, 最 適解が規格断面からかけ離れたものとなるという問題が生じる場合 がある。このため, リストの規格断面を良好に表現できるように代 表寸法を選び，これを独立設計変数として残りの寸法を線形関数で 与える。例えば H 形鋼で規格断面リストに JIS G 3192 15 )の汎用品 を用いる場合, せい $H_{i}$ と幅 $B_{i}$ を独立設計変数とし(すなわち $\left.\boldsymbol{x}_{\boldsymbol{i}}=\left\{H_{i}, B_{i}\right\}\right)$, ウェブ厚 $t_{1 i}$ ・フランジ厚 $t_{2 i}$ を次の寸法比を用いて従 属的に定める。

$$
B_{i} / t_{1 i}=22.5, B_{i} / t_{2 i}=14.5
$$

ここに $22.5,14.5$ は, 規格断面リストにおける当該寸法比の平均值 である。式(5)で $t_{1 i}$ の決定にウェブ幅厚比に準じる $H_{i} / t_{1 i}$ ではなく $B_{i} / t_{1 i}$ を用いるのは, 同リストでは後者の方がばらつきが小さく, 規格断面に近い最適解が得やすいことによる。

図 1 には, 規格断面および式(5),(6)に基づく近似断面の断面 2 次 モーメント(強軸まわり)を示す。ある規格断面およびそれと同じ

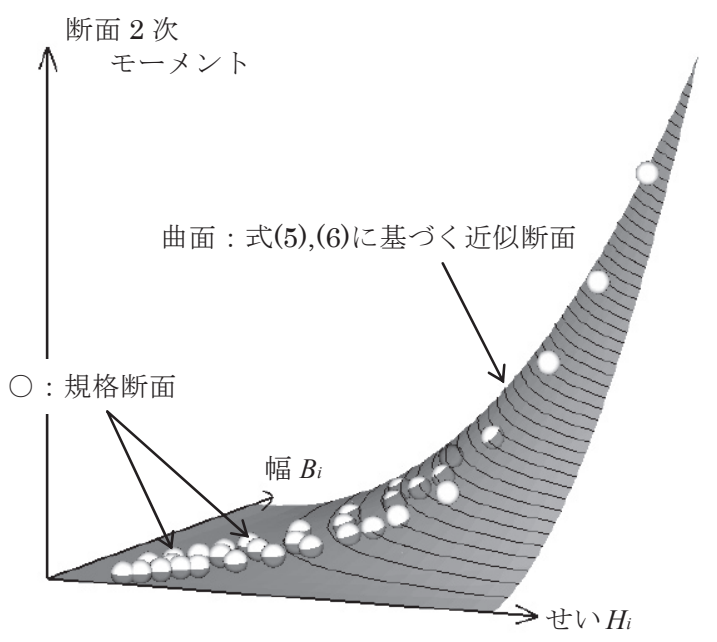

図 1 規格断面之近似断面(曲面) 
$H_{i}, B_{i}$ をもつ近似断面の断面 2 次モーメントをそれぞれ $I, \breve{I}$ とす ると, $I / I$ の全規格断面に関する平均值は 0.98 , 標準偏差は 0.19 である。同様に，断面積ではそれぞれ $0.98 ， 0.21$ である。式(5),(6) による断面が規格断面を断面性能という面で概ね良好に近似してい ることがわかる。なお, 円形鋼管や角形鋼管についても, 必要に応 じて外形寸法のみを独立設計変数とし, 厚さはそれに対する比(それ ぞれ 39.3，28.6)を与えて従属的に定める。

\section{2. 制約条件}

設計変数ベクトルの各成分の上下限制約の他, 応力や変位, 断面 寸法に関する制約を考慮する。応力については, 部材 $j \in S_{i}$ の圧縮 もしくは引張応力と曲げ応力との組合せ応力に関する応力度比 (存 在応力度の許容応力度 ${ }^{16)}$ に対する比で正值)を $r_{j}(\boldsymbol{x})^{\text {注 } 1)}, S_{i}$ の応力度 比を $R_{i}(\boldsymbol{x})=\max _{j \in S_{i}}\left\{r_{j}(\boldsymbol{x})\right\}$ とし, これを指定最大值 $\overline{R_{i}^{u}}(\leq 1)$ 以下とす る(以下, 応力度比制約と呼ぶ)。なお, 複数の荷重ケースを考慮す る場合は, それらによって部材 $j$ に生じる最大の応力度比を $r_{j}(\boldsymbol{x})$ と する。

$$
1-R_{i}(\boldsymbol{x}) / \overline{R_{i}^{u}} \geq 0
$$

断面寸法については, 図 1 の近似曲面上で規格断面が近傍に分布 する領域で最適解が求まるよう, 外形寸法に関する制約 $1-B_{i} / H_{i} \geq 0$ や幅厚比制約 16)を設ける。この他, 異なるグループ間 の断面寸法に関する制約(例 : 異なる $i$ について $H_{i}$ を同一とする)を 考慮する。

\section{3. 最適化手法および感度計算手法}

最適化手法には逐次 2 次計画法 ${ }^{17)}$ 用いる。目的関数や制約関数 の感度係数は差分法を用いて近似的に計算する。これにより, 許容 応力度や式(7)の制約関数式に含まれる不連続性の問題は擬似的に 解消される。

\section{3. 自動グループ分割手法}

\section{1. 最適グループ細分割問題の定式化}

前章の断面最適化問題の最適解を $x^{*}$ とする。 $x^{*}$ に対応する諸量 についても同様に ( ) と表記し, 変数名の前に「最適」を付ける。 断面最適化では部材グルーピング $\boldsymbol{S}=\left\{S_{i}\right\}\left(i=1,2, \cdots, n_{S}\right)$ を与条件と したが, 最適解の性能は $\boldsymbol{S}$ に大きく依存する。例えばすべての部材 を同一グループに分類すれば, 最適解ではごく一部の部材が応力度 比制約をちょうど満足して大多数の部材には圥長性が残されること になるので, 最適コスト $P^{*}(\boldsymbol{S})$ は大きな值に留まる。逆にすべての 部材を互いに異なるグループとすれば， $P^{*}(\boldsymbol{S})$ は限界まで小さくな るものの, そのような解は断面・接合部の種類が多く現実にはかえ って高コストとなる。また, 構造設計者が与えるグルーピングには 節・階等の位置情報や, 柱・梁や弦材・斜材等の役割が反映されて いることが多く, これらを無視してグループを改変することは構造 設計の総合的な質の低下に繋がってしまう。

これらを考慮して本章では, あるグループ $S_{i}$ を 2 分割して $P^{*}$ を 改善(低減)し, 低減効果が最も大きくなるグループの選定方法およ びその分割方法について考える。問題の定義を示す。

\section{最適グループ細分割問題}

初期の部材グルーピング $\boldsymbol{S}=\left\{S_{i}\right\}\left(i=1,2, \cdots, n_{S}\right)$ の下で, 断面最 適化問題の最適解 $\boldsymbol{x}^{*}(\boldsymbol{S})$, 最適コスト $P^{*}(\boldsymbol{S})$ 等が得られている とする。ある $S_{i}$ を $S_{i, 1}$ と $S_{i, 2}\left(=S_{i}-S_{i, 1}\right)$ に分割したグルーピング $S^{\prime}$ を考えたとき, $P^{*}\left(S^{\prime}\right)$ が最小となるようなグループ $i$ とその 分割 $S_{i, 1}, S_{i, 2}$ を求めよ。

これは組合せ最適化問題であるので, 㛜密解を得るにはす心゙ての組 合せに対して断面最適化問題を解く必要があり膨大な計算負荷を要 する。また, 厳密解が得られてもそれは単に総部材コストが最小と なる設計解であって, 接合部の納まり等の現実的要因を加味した修 正を必要とすることが予想される。従って, ここでは以下の緩和条 件を導入し, 良好な近似最適解を効率的に求める方法を提案する。

\section{緩和条件}

$S_{i}$ から $S_{i, 1}, S_{i, 2}$ への分割は, 各部材の最適応力度比 $r_{j}^{*}(\boldsymbol{S})$ のみ を用いて行う。つまり, 応力度比の閾值(分割応力度比)を $\rho_{i}$ と し, 部材 $j \in S_{i}$ を $r_{j}^{*}(\boldsymbol{S})<\rho_{i}$ のとき $S_{i, 1}, r_{j}^{*}(\boldsymbol{S}) \geq \rho_{i}$ のとき $S_{i, 2}$ に 振り分ける。

これにより, 最適グループ細分割問題は $P^{*}\left(\boldsymbol{S}^{\prime}\right)$ が最小となる $\left(i, \rho_{i}\right)$ を求める問題に緩和される。

\section{2. 最適コスト低減効果予測式の提案}

緩和条件を導入してもなお, 最適グループ細分割問題は連続变数 を用いた断面最適化を伴う組合せ最適化問題である。これを近似的 ながら効率的に解くために, 分割による $P^{*}$ の低減効果 $Q=P^{*}(\boldsymbol{S})-P^{*}\left(\boldsymbol{S}^{\prime}\right)$ を分割前の諸量を用いて簡便に予測する手法を 提案する。

$S_{i}$ を $S_{i, 1}$ と $S_{i, 2}$ に分割してあらためて最適化(再最適化)を実行す ると, 概して, $r_{j}^{*}(\boldsymbol{S})$ が大きい $S_{i, 2}$ の断面はあまり変化せず, $r_{j}^{*}(\boldsymbol{S})$ が 小さい $S_{i, 1}$ の断面が応力度比制約がアクティブになる(式(7)が等号 で満足される)まで小さくなって $P^{*}$ の低減に寄与する。部材断面力 は再最適化の前後で不変であり, 各部材の応力度比は断面積ひいて は部材コストに反比例するという近似的な仮定に基づけば，再最適 化後の $S_{i, 1}$ の部材コストは再最適化前の $\rho_{i}^{d} / \overline{R_{i}^{u}}$ 倍になると予想さ れる。ここに, $\rho_{i}^{d}=\max _{j \in S_{i, 1}}\left\{r_{j}^{*}(\boldsymbol{S})\right\}$ である。以上を踏まえ, $Q$ を次 の指標 $\widetilde{Q}\left(i, \rho_{i}\right)$ を用いて予測することを提案する。

$$
\widetilde{Q}\left(i, \rho_{i}\right)=\left(1-\rho_{i}^{d} / \overline{R_{i}^{u}}\right) \beta_{i} \sum_{j \in S_{i, 1}} w_{j}^{*}(\boldsymbol{S})
$$

初期グルーピング $\boldsymbol{S}=\left\{S_{1}, \cdots, S_{i}, \cdots, S_{n_{S}}\right\}$ の下で最適化を行って $\boldsymbol{x}^{*}(\boldsymbol{S}), r_{j}^{*}(\boldsymbol{S})$ 等を得た後に, 次の STEP 1〜3 を実行すれば, 効果的 に $P^{*}$ を低減することができる。

STEP 1. 全てのグループi $i$ にいて， $\rho_{i}$ を 0 から $\overline{R_{i}^{u}}$ まで刻み幅 $\overline{\Delta \rho_{i}}$ でパラメトリックに变化させながら式(8)の $\widetilde{Q}$ を計算し, そ れが最大となる $\left(i, \rho_{i}\right)$ を見出す。なお, 同式は極めて簡単なので 計算負荷は小さい。

STEP 2. 上記の $\left(i, \rho_{i}\right)$ に対応するグルーピングを，新たなグルー ピング $\boldsymbol{S}^{\prime}=\left\{S_{1}, \cdots, S_{i, 1}, S_{i, 2}, \cdots, S_{n_{S}}\right\}\left(\right.$ グループ数は $\left.n_{S}+1\right)$ とする。 STEP 3. $x^{*}(S)$ を初期解とし， $S^{\prime}$ の下で再最適化を実行する。 


\section{3. 例題による予測式の検証}

\subsection{1 平面トラス状架構}

図 2 の平面トラス状架構を用いて, 式(8)の予測值 $\widetilde{Q}\left(i, \rho_{i}\right)$ が真值 $Q$ を良好に近似することを例証する。初期の部材グルーピングは $\boldsymbol{S}=\left\{S_{i}\right\} \quad(i=1,2$ の順で弦材, 斜材 $)$ で, $S_{1}$ は $\boldsymbol{x}_{1}=\left\{H_{1}, B_{1}\right\}$ を独立設 計変数とする $\mathrm{H}$ 形鋼, $S_{2}$ は $\boldsymbol{x}_{2}=\left\{D_{2}\right\}\left(D_{2}\right.$ : 外径 $)$ を独立とする鋼管 である。それぞれ, 厚さは 2 章の寸法比を用いて定める。応力度比 の指定最大值は $\overline{R_{i}^{u}}=0.9$ とする。図 3 に, 求めた最適断面寸法を弦 材の最適応力度比 $r_{j}^{*}$ とともに示寸(同一太さ・濃さの部材は同一グ ループを表す。線の太さが断面積等を表しているわけではない。以 降の図も同様)。最適コストは $P^{*}(\boldsymbol{S})=17.06$ となった。ここでは鋼材 の質量単価を $\beta_{i}=1$ としたため, $P^{*}$ はそのまま鉄骨質量(ton)を表す。

図 4 は, グループ毎に $r_{j}^{*}(\boldsymbol{S})$ が小さい順に部材番号を付け直した 上で, 各部材 $j \in S_{i}$ の $r_{j}^{*}(\boldsymbol{S})$ を横軸に, 部材コストの累計值 $V_{i, j}=\sum_{k=1}^{j} \beta_{i} w_{k}^{*}(\boldsymbol{S})$ を縦軸にプロットしたものである。 $S_{1}, S_{2}$ それぞ れ 1 部材のみで $r_{j}^{*}(\boldsymbol{S})=\overline{R_{i}^{u}}$ となり, その他多くの部材には圥長性が 残されている。例えば $S_{1}$ を応力度比 0.6 を境に分割する場合, $\widetilde{Q}\left(i, \rho_{i}\right)$ は同図中の $a, b$ を用いて $\widetilde{Q}(1,0.6)=a b / \overline{R_{1}^{u}}$ となる。図 5 の実 線は， $\rho_{i}$ を 0 $\overline{R_{i}^{u}}$ までパラメトリックに変化させて $\widetilde{Q}-\rho_{i}$ 関係を 求めたものである。ここでは精緻な作図のため $\overline{\Delta \rho_{i}}=\overline{R_{i}^{u}} / 1000$ とし た。しかし， $\widetilde{Q}$ が最大となる $\left(i, \rho_{i}\right)$ のみが重要であることや, $r_{j}^{*}(S)$ が部材毎の離散值をとるので近接する $r_{j}^{*}(\boldsymbol{S})$ 間では $\rho_{i}$ がどのような 值をとっても予測值 $\widetilde{Q}$, 真值 $Q$ ともに不変であることを考えれば, $\overline{\Delta \rho_{i}}$ はあまり小さくする必要はなく, 通常は $\overline{\Delta \rho_{i}}=\overline{R_{i}^{u}} / 100$ 程度で十 分である。 $S_{2}$ より $S_{1}$ を分割する方が $\widetilde{Q}$ は大きく, $\rho_{1}=0.501^{+} \sim$ 0.635 の時に最大值 3.71 をとることがわかる。同図にはあわせて, $\rho_{i}$ を変化させる際に出現したすべての $\boldsymbol{S}^{\prime}=\left\{S_{1,1}, S_{1,2}, S_{2}\right\}$ について断 面最適化を実行して求めた $Q$ をプロットする。 $\widetilde{Q}$ が $Q$ を概敉良好 に近似していることがわかる。なお， $Q$ は $\rho_{1}=0.486 \sim 0.501$ の時 に最大值 3.96 をとっており, 最大の $\widetilde{Q}$ をえる $\rho_{1}$ はこれを僅かに 外しているが, 十分に実用的な範囲と言える。図 6 には, 最大の $\widetilde{Q}$ を与える $\left(i, \rho_{i}\right)$ に従って $\boldsymbol{S}^{\prime}$ を構成して再最適化を実行した結果を 示す。圥長性の高かった $S_{1,1}$ で部材断面が大きく減少し, $P^{*}\left(S^{\prime}\right)$ は $P^{*}(\boldsymbol{S})$ から $20 \%$ 減の 13.65 となった。以降, $\widetilde{Q}$ を用いてグループ分 割・再最適化を行うことを自動グループ分割と呼ぶ。

\subsection{2 平面ラーメン架構}

図 7 の平面ラーメン架構を用いて, 曲げ抵抗型の架構についても 式(8)の予測值 $\tilde{Q}\left(i, \rho_{i}\right)$ が真值 $Q$ を良好に近似することを例証する。 初期の部材グルーピングは $\boldsymbol{S}=\left\{S_{i}\right\} \quad\left(i=1,2\right.$ の順で柱, 梁)で, $S_{1}$ は $\boldsymbol{x}_{1}=\left\{A_{1}\right\}$ ( $A_{1}$ : 外法辺長 $)$ の角形鋼管, $S_{2}$ は $\boldsymbol{x}_{2}=\left\{H_{2}, B_{2}\right\}$ の $\mathrm{H}$ 形鋼で ある。厚さは 2 章の寸法比で定める。各節点には鉄骨質量および梁 長さ $1 \mathrm{~m}$ あたり 5 ton に相当する集中質量が配置されている。鉛直下 向き荷重を $W=1.0 \mathrm{~g}(\mathrm{~g}$ 重力加速度), 水平荷重を $E=0.4 \mathrm{~g}$ 注 2) とし, $W \pm E$ を短期荷重ケースとして作用させる(荷重ケース数は 2 )。層 間変形角に関する制約は考慮しない。 $\overline{R_{i}^{u}}=0.9$ として求めた最適断 面寸法を，柱の $r_{j}^{*}$ とともに図 8 に示す。最適コストは $P^{*}(\boldsymbol{S})=20.32$ となった。本例題でも $\beta_{i}=1$ であり,$P^{*}$ は鉄骨質量(ton)を表す。

図 9 に $\widetilde{Q}\left(i, \rho_{i}\right)$ と $Q$ の比較を示す。 $S_{1}, S_{2}$ の両方で予測精度は概 放良好である注 3 。 $\widetilde{Q}, Q$ の最大值はともに $\rho_{1}=0.361 \sim 0.525$ の範

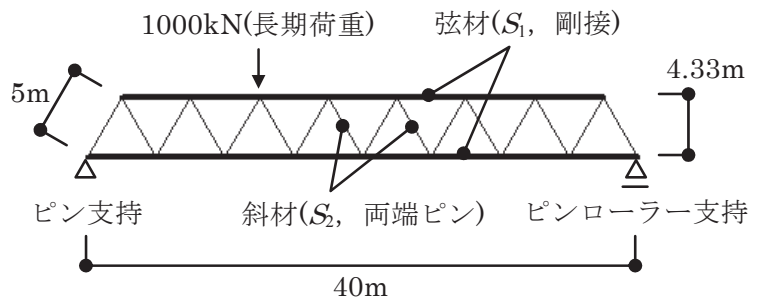

※長期荷重に部材自重も考慮。設計基準強度 $\mathrm{F}=235 \mathrm{~N} / \mathrm{mm}^{2}$

図 2 平面卜ラス状架構

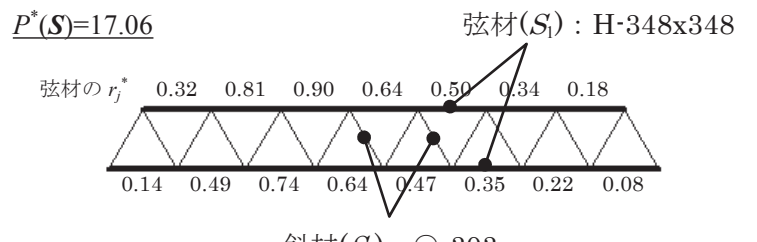

斜材 $\left(S_{2}\right): \bigcirc-303$

図 $3 \quad S$ の下での最適解

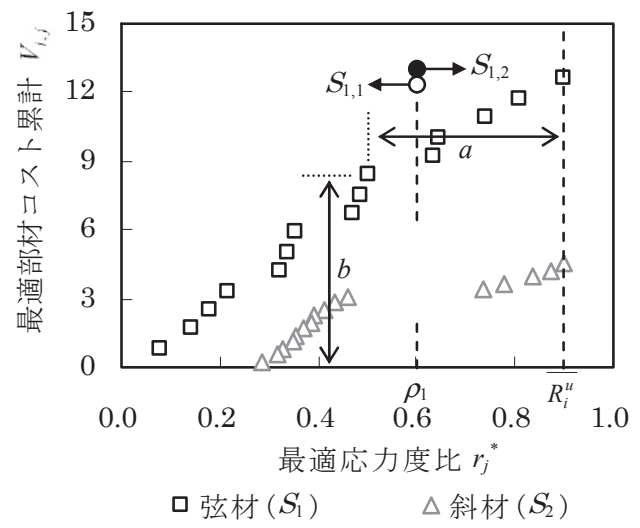

図 $4 \quad S$ の下での最適部材コスト累計と最適応力度比

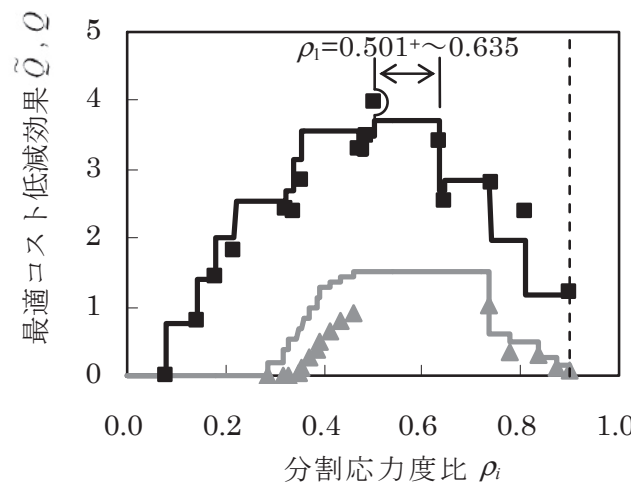

$\begin{array}{ll}-S_{1} \text { 分割 (予測) } & S_{2} \text { 分割 (予測) } \\ S_{1} \text { 分割 (真值) } & S_{2} \text { 分割 (真値) }\end{array}$

図 5 最適コス卜低減効果一分割応力度比関係(予測・真值) $\underline{P^{*}\left(\boldsymbol{S}^{\prime}\right)=13.65}$

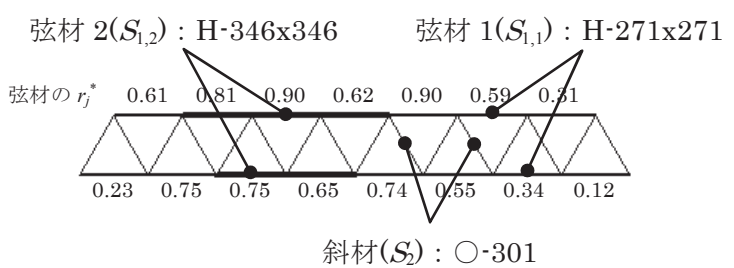

図 $6 S^{\prime}$ の下での最適解 
囲で現れ，それぞれ $3.83,3.73$ である。 $\widetilde{Q}$ そる簡便な予測で最も コスト低減効果の高い $\left(i, \rho_{i}\right)$ を特定できたことになる。図 10 には, 特定した $\left(i, \rho_{i}\right)$ に従って $\boldsymbol{S}^{\prime}=\left\{S_{1,1}, S_{1,2}, S_{2}\right\}$ を構成して再最適化を実 行した結果を示す。支持荷重の小さい第 2 層の外柱と第 3 層の柱が $S_{1,1}$ に分類されて断面が小さくなっており, 妥当な結果と言える。

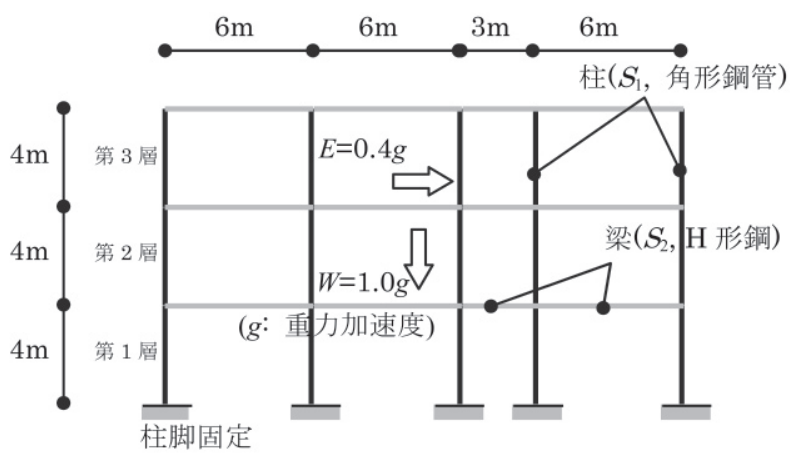

※各節点には, 鉄骨質量および梁長さ $1 \mathrm{~m}$ あたり 5 ton に 相当する集中質量を配置。設計基準強度 $\mathrm{F}=235 \mathrm{~N} / \mathrm{mm}^{2}$

図 7 平面ラーメン架構

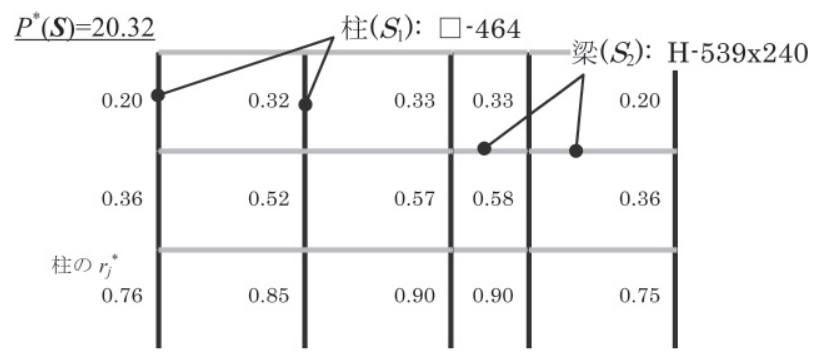

図 $8 \quad S$ の下での最適解

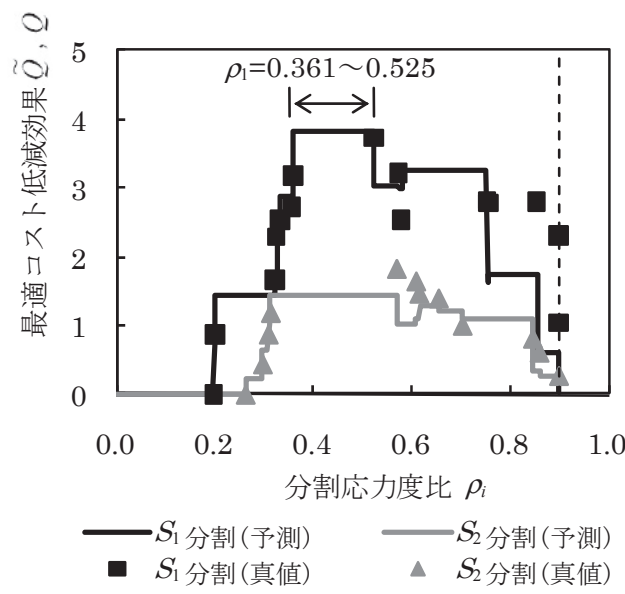

図 9 最適コスト低減効果一分割応力度比関係 (予測・真值)

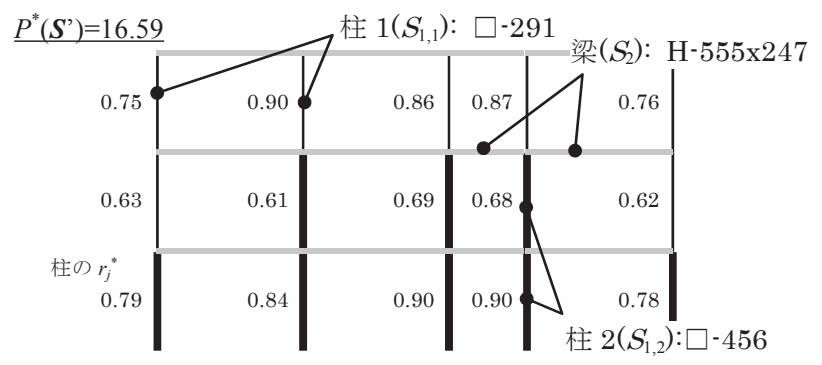

図 $10 \quad S^{\prime}$ の下での最適解

\section{4. 対話型グルーピングによる設計支援システムの提案}

自動グループ分割を複数回適用すれば, 総部材コストの観点から 望ましい部材グルーピングに効率的に到達することができるが，実 際の建築物には他にも考慮すべき重要な要素が多くある。例えば, 部材断面の種類(グループ数)は少なくてもその組合せである接合部 の種類が多いような場合, 断面の統一化の効果は現れ難い。また, 詳細な製作性や施工性等, 構造設計段階で考慮はされるが定量化や 判断のアルゴリズム化が困難なものも多い。

構造設計者が多種多様な要件を自ら反映して総合的に満足できる 設計解に到達するために，ここでは自動グループ分割に対話型のグ ルーピング修正操作を加えた設計支援システムを提案する。図 11 にフローを示寸が，これはシステムがある条件下における最適解の 性状(グルーピングの状態やアクティブな制約条件, 応力度比分布, コスト等)を提示し，構造設計者がその情報を基に総合的な観点から グルーピングを修正するというやり取りを繰り返して, 最終的に満 足する設計解に到達するものである。以下に, フローに含まれる (1) 〜6の操作を説明する。

\section{(1)長部材のグループ移動}

自動グループ分割(グループ分割・再最適化)を実行すると，基本 的に $S_{i, 1}$ の断面の方が $S_{i, 2}$ より 小さくなる。再最適化によって部材 断面力は変化するので, $S_{i, 2}$ の部材の中から $S_{i, 1}$ の断面でも応力度 比制約を満足するものが出現する場合があるが，ここではそのよ うな部材を自動的に検出して $S_{i, 1}$ に移動する。なお，他の制約条 件が支配的で応力度比制約がアクティブでないグループがある場 合は特に, 移動後の再最適化によって $P^{*}$ が逆に増加することがあ る。本論では, そのような $P^{*}$ の増加を事前に予測するのではなく, 増加した場合に移動前のグルーピングおよび解に戻ることとする。

\section{(2)指定部材のグループ移動}

部材を指定して所属グループを変更する。これは, 総部材コスト が多少増加しても接合部の標準化を優先したい場合等に行う。

\section{(3)グループ統合}

複数のグループを統合して 1 つのグループとする。これは，異な るグループの最適断面寸法に大きな差異が見られない場合, つま り別々のグループとする意義が小さい場合等に行う。

\section{(4)断面寸法制約の変更}

梁せいを揃える等，異なるグループ間の断面寸法に関する制約を 追加・変更もしくは解除する。

\section{(5)指定グループ分割}

分割グループと分割応力度比を指定してグループ分割を行う。

\section{(6)設計対象の解除・再選択}

グループ数を増やすと設計変数や制約条件の数が増えるので，最 適化にかかる計算時間も増加する。一方，上記(1)〜(5)の操作を経 た後の再最適化では, 操作を施さなかったグループの断面は基本 的にあまり変化しないので，常にすべてのグループの断面を設計 変数とする必要性は小さい。ここでは, 指定したグループを設計 変数や制約条件から除外もしくは必要に応じて再選択する。 本システムにより，部材コストの観点から論理的なグルーピングを 行うこと,さらにはそれを総合的観点から調整することが可能とな る。なお，それぞれのグルーピングにおける断面は，前の条件にお ける最適解を初期解と寸る断面最適化により効率的に求められる。 


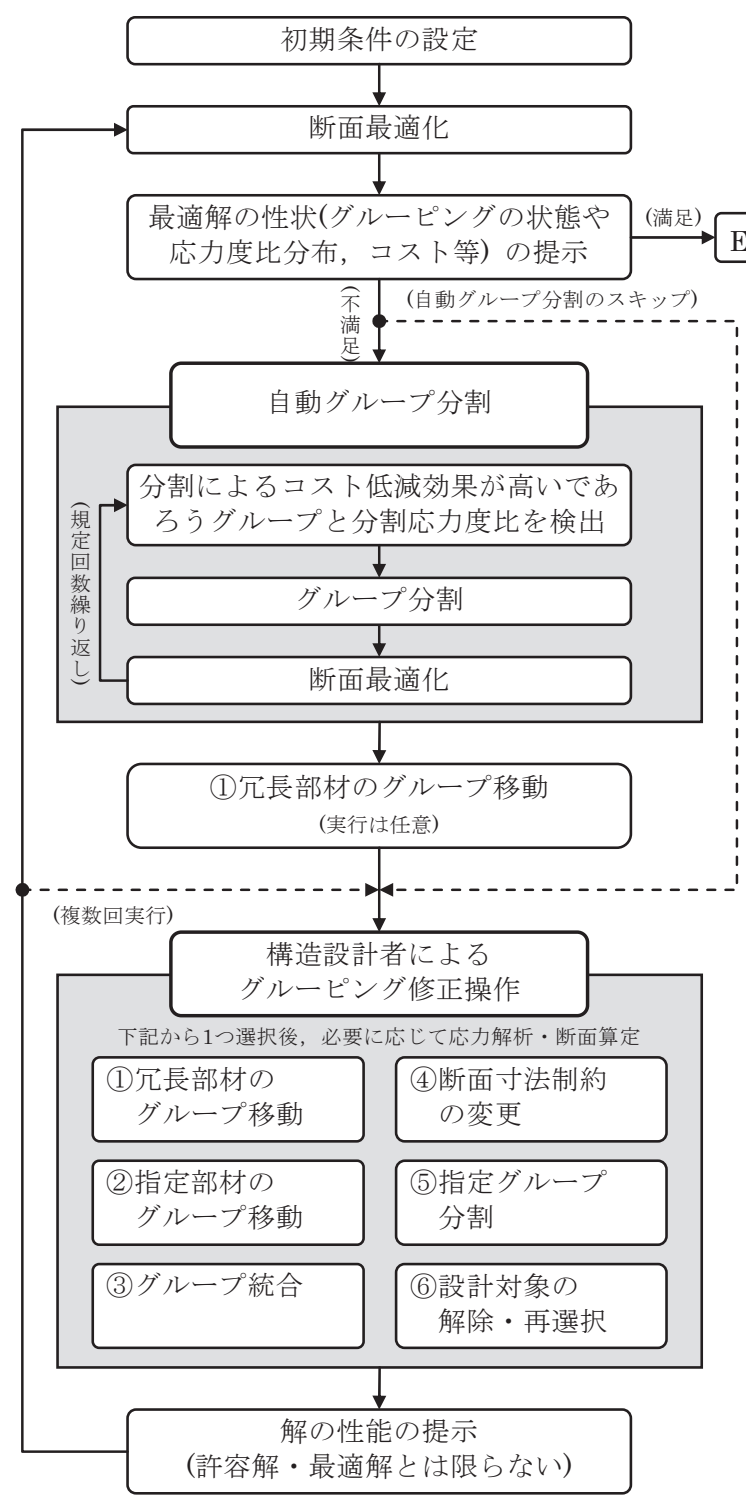

図 11 設計支援システムのフロー

\section{5. 例題}

ここでは, 図 11 のフローに基づいて構築した設計支援システムを 用いて, 図 12 に示寸立体トラス状架構の試設計を行う。上弦面・ 下弦面は XY 平面位置がずれた $5 \mathrm{~m}$ 角の格子となっており, それら を長さ $5 \mathrm{~m}$ の斜材が繋いでいる。部材数は 432 , 節点数は 124 であ る。下弦格子の $-\mathrm{Y}$ 側長辺の全節点および $+\mathrm{Y}$ 側の $\pm \mathrm{X}$ 端は鉛直支 持 $(\mathrm{Z}$ 方向支持)されており, 鉄骨自重に加えて上弦面の各節点に $3.2 \mathrm{kN} / \mathrm{m}^{2}$ に相当する節点荷重が長期荷重として載荷される。格子材 は両端剛接合の $\mathrm{H}$ 形鋼, 斜材は両端ピン接合の鋼管で, 設計基準強 度はともに $F=325 \mathrm{~N} / \mathrm{mm}^{2}$ とする。許容応力度の算定においては, 節点間距離すなわち $5 \mathrm{~m}$ を個材の座屈長さとする。以下にシステム を用いた設計過程の例を説明するが，断面最適化においては指定最 大応力度比を $\overline{R_{i}^{u}}=0.9$ とする応力度比制約および $\mathrm{H}$ 形鋼のウェブ幅 厚比制約等を考慮する。フランジ幅厚比および鋼管の径厚比につい ては，2 章の寸法比を用いることで自動的に満足される。なお，格

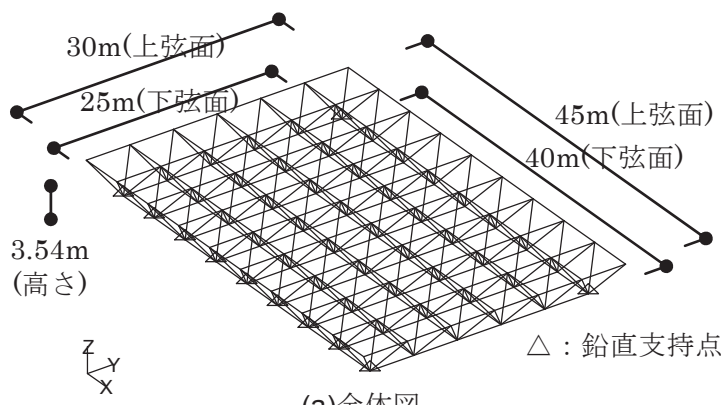

(a)全体図

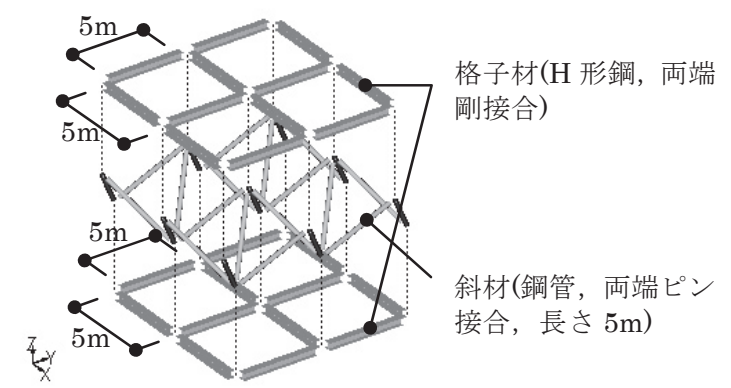

(b)構成図(部分拡大)

図 12 立体トラス状架構

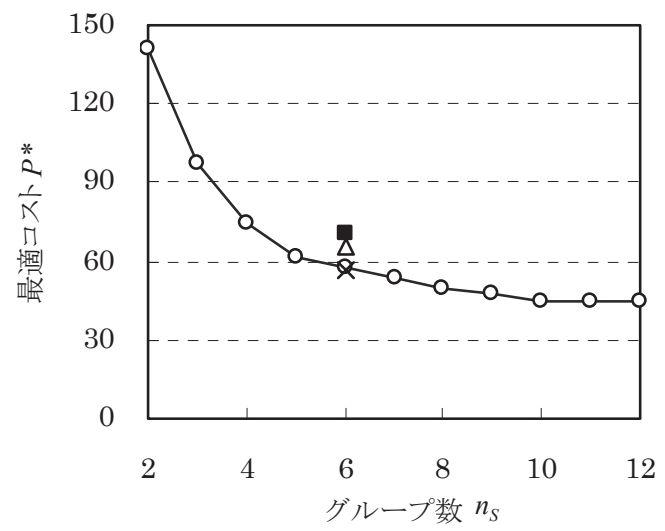

——-1）自動グループ分割 $\times 2 ）$ 自動グループ分割

$\Delta$ 3）格子材せい統一、 4）JIS規格断面

図 $13 \quad P^{*}-n_{S}$ 関係

子材では $150 \leq H_{i} \leq 1000$ および $75 \leq B_{i} \leq 1000$, 斜材では $21.7 \leq D_{i} \leq 1000$ (単位は $\mathrm{mm}$ ) の設計変数上下限制約を設ける。

\section{1) 部材グループ数の決定}

まず, 最適コスト $P^{*}$ と部材グループ数 $n_{S}$ の関係を把握し, 適切 な $n_{S}$ を決定する。図 13 は, 格子材(上下弦面とも)および斜材の $n_{S}=2$ から自動グループ分割を繰り返して求めた $P^{*}-n_{S}$ 関係であ る(図中の $\times, \triangle, \boldsymbol{\square}$ については後述する)。ここで, 鋼材の質量単 価は $\beta_{i}=1$ としているため， $P^{*}$ はそのまま鉄骨質量(ton)を表す。 $n_{S}=2$ の場合に約 140 だった $P^{*}$ は $n_{S}$ の増加に伴って急激に減少す るが，その度合いは徐々に鈍化し， $n_{S} \geq 10$ ではほぼ一定で約 45 と なる。 $n_{S}=12$ では格子材から派生したグループの一部でせいが下限 值に抵触し，その中では幅が近いものも発生しているので，これ以 上分割しても $P^{*}$ はあまり減少しない。なお，自動グループ分割では $P^{*}$ の低減効果の高いグループを検出して分割するため, 格子材と斜 
材のグループ数は必ずしも同じではなく， $n_{S}=12$ ではそれぞれ 8 および 4 グループとなった。図 14 および図 15 には， $n_{S}=2$ および 12 の時の最適応力度比 $r_{j}^{*}$ のヒストグラムを示寸。両図の縦軸のス

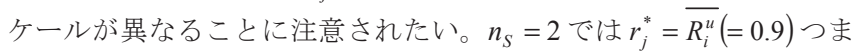
り応力度比制約がアクティブとなる部材はごく僅かで, 約半数の部 材で $r_{j}^{*} \leq 0.1$ となる不経済な設計解となっている。これに対し $n_{S}=12$ の場合は $r_{j}^{*}$ の高值の領域に多くの部材が分布しており, 部 材の断面性能を効率的に活用できていることがわかる。ただし, 本 架構で 12 種類もの断面を許容することは接合部の標準化等の観点 から好ましくない。以下では, 少ない $n_{S}$ で比較的小さな $P^{*}$ が得ら れている $n_{S}=6$ を採用寸る。この時の最適コストは $P^{*}=57.83$ であ る。

\section{2) 自動グループ分割および冗長部材のグループ移動}

次に, 格子材と斜材のグループ数が同数となるように制御しなが らあらためて自動グループ分割を $n_{S}=2$ から $n_{S}=6$ まで 4 回繰り返 し, さらに図 11 の11示寸咒長部材のグループ移動を 1 回行った 上で断面最適解を求めた。表 1 に最適断面寸法を, 図 16 に $r_{j}^{*}$ の七 ストグラムを示す。図 17 には上弦格子面・斜材・下弦格子面のそ れぞれについて断面の分布すなわちグルーピングの状態を示す。概

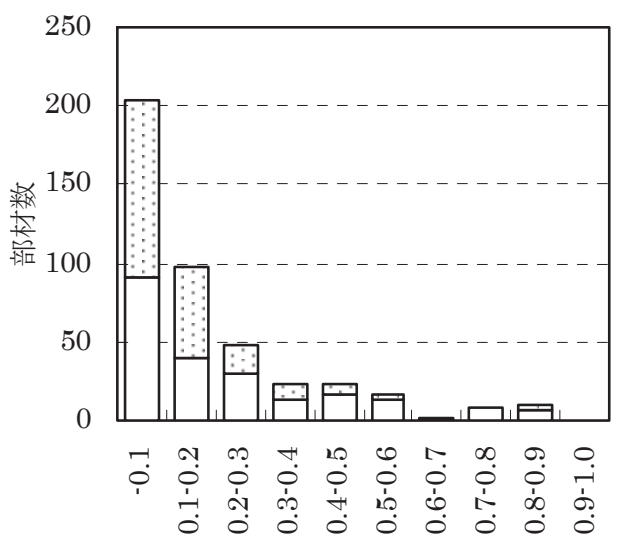

最適応力度比 $r_{j}^{*}$

口格子材田斜材

図 $14 n_{S}=2$ の時の $r_{j}^{*}$ ヒストグラム

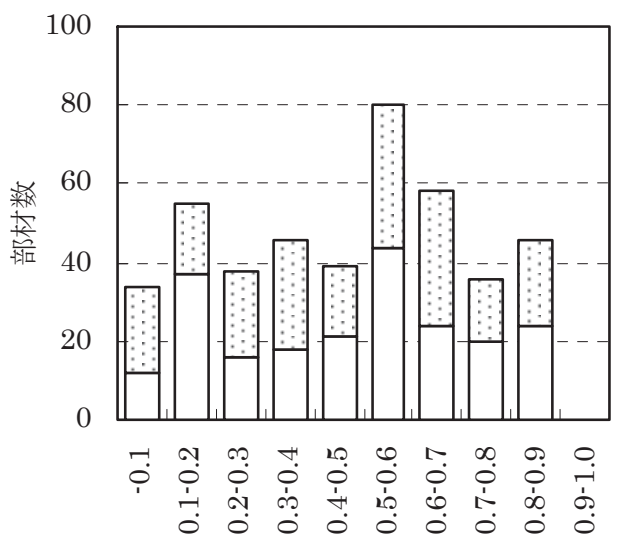

最適応力度比 $r_{j}^{*}$

口全格子材田全斜材

図 $15 n_{S}=12$ の時の $r_{j}^{*}$ ヒストグラム
して -Y 側に開いたコの字状に大きな断面が配置されており，支持 点位置に応じた妥当な結果となっている。なお, これは上記 1)の $n_{S}=6$ 時と同じグルーピングではないが， $P^{*}$ は図 13 の×に示すよ うに 56.74 となっており，1)との差はごく僅かである。

\section{3) 格子材せいの統一}

表 1 のうにせいが異なる $\mathrm{H}$ 形鋼を剛接合すると接合部の納まり が複雑となり，全体として高コストの架構になりがちである。そこ で，図 11 の(4)にるように異なる断面間の寸法制約を変更する。 具体的には，格子材 $\mathrm{A}, \mathrm{B}, \mathrm{C}$ の部材せいをすべて同一とする制約を 追加した上で, 上記 2)の最適解を初期解としてあらためて断面最適 化を行った。表 2 に最適断面寸法を, 図 18 に $r_{j}^{*}$ のヒストグラムを 示寸。図 13 には, この時の $P^{*}=65.09$ を $\triangle$ で示す。格子材 $\mathrm{C}$ の $r_{j}^{*}$ は 最大でも 0.59 で応力度比には余裕があるが, これはせいを格子材 $\mathrm{A}$ $\mathrm{B}$ と同一の大きな值とした一方, 幅をこれ以上小さくするとウェブ 幅厚比制約が満足されなくなるためである。 $\mathrm{H}$ 形鋼のウェブ厚は幅 に対する寸法比で定めていることに注意されたい。

\section{4) JIS 規格断面の選択}

最後に，3）で得られた解に近い断面を JIS 規格断面リストから選 択し, あらためて応力解析・断面算定を行う。表 3 に選択した断面 を示すが，選択にあたっては適宜ユーザ(構造設計者)の判断を加え

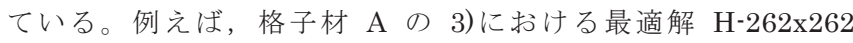
(x11.6x18.0)にせい・幅が近い規格断面は H-250x250x9x14 と $\mathrm{H}-300 \times 300 \times 10 \times 15$ だが，前者では全ての寸法が最適解より小さい ので 0.9 以下に抑えていた応力度比が 1 を超える可能性が高いと判 断し, 後者を選択している。なお, この選択過程には若干の試行錯 誤が生じることもある。図 19 には $r_{j}^{*}$ のヒストグラムを示す。 $r_{j}^{*}$ の 分布は 2)や3)に比してやや低值側にシフトしているものの, 概齐断 面性能を効率的に利用している。この時のコストは図 13 のロに示 すように $P^{*}=70.95$ で, 先述の 2)に比して約 $25 \%$ 増となっている。 2)は格子材にせいの異なるビルトアップ $\mathrm{H}$ 形鋼を用いた解であるこ とを考えると，せいが揃った JIS 規格断面を用いる本解は製作上・ 施工上の優位性が高く, 総合的により良い設計解と言える。

表 1 最適断面寸法

\begin{tabular}{|c|c|c|}
\hline \multicolumn{2}{|c|}{ グループ } & 最適断面寸法 \\
\hline \multirow[t]{3}{*}{ 格子材 } & $\overline{\mathrm{A}}$ & "H-261x261(x11.6x18.0) \\
\hline & B & $\mathrm{H}-170 \mathrm{x} 170(\mathrm{x} 7.6 \mathrm{x} 11.7)$ \\
\hline & $\mathrm{C}$ & $\mathrm{H}-150 \times 118(\mathrm{x} 5.3 \times 8.1)$ \\
\hline \multirow[t]{3}{*}{ 斜材 } & A & - $242(x 6.2)$ \\
\hline & B & $\bigcirc-150(x 3.8)$ \\
\hline & $\mathrm{C}$ & $0-110(x 2.8)$ \\
\hline
\end{tabular}

表 2 最適断面寸法

\begin{tabular}{cc|l}
\multicolumn{2}{c}{ 表 2} & 最適断面寸法 \\
\hline \multicolumn{2}{c|}{ グループ } & \multicolumn{1}{c}{ 最適断面寸法 } \\
\hline \hline 格子材 & $\mathrm{A}$ & $\mathrm{H}-262 \times 262(\mathrm{x} 11.6 \times 18.0)$ \\
& $\mathrm{B}$ & $\mathrm{H}-262 \times 173(\mathrm{x} 7.7 \mathrm{x} 12.0)$ \\
& $\mathrm{C}$ & $\mathrm{H}-262 \mathrm{x} 136(\mathrm{x} 6.0 \mathrm{x} 9.4)$ \\
\hline 斜材 & $\mathrm{A}$ & $\bigcirc-242(\mathrm{x} 6.2)$ \\
& $\mathrm{B}$ & $\bigcirc-144(\mathrm{x} 3.7)$ \\
& $\mathrm{C}$ & $\bigcirc-110(\mathrm{x} 2.8)$ \\
\hline
\end{tabular}




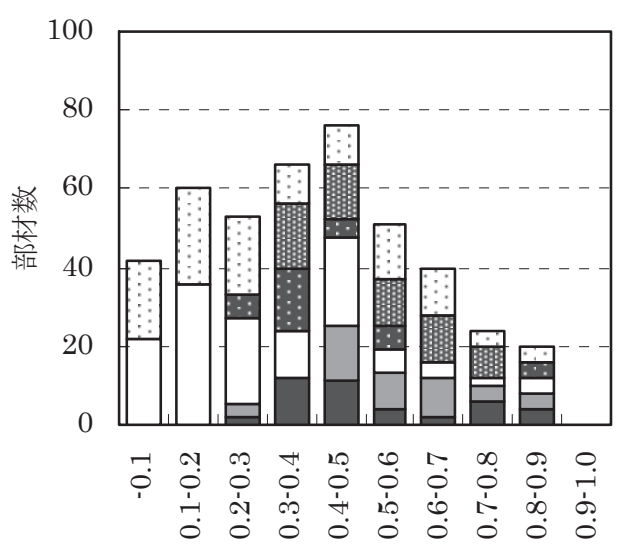

最適応力度比 $r_{j}^{*}$

$\begin{array}{lll}\text { 口格子材 } \mathrm{A} & \square \text { 格子材 } \mathrm{B} & \square \text { 格子材 } \mathrm{C} \\ \text { 回斜材 } \mathrm{A} & \text { 橉斜材 } \mathrm{B} & \text { 口斜材 } \mathrm{C}\end{array}$

図 $16 n_{S}=6$ (格子材 3 , 斜材 3 )の場合の $r_{j}^{*}$ ヒストグラム

$Y x$

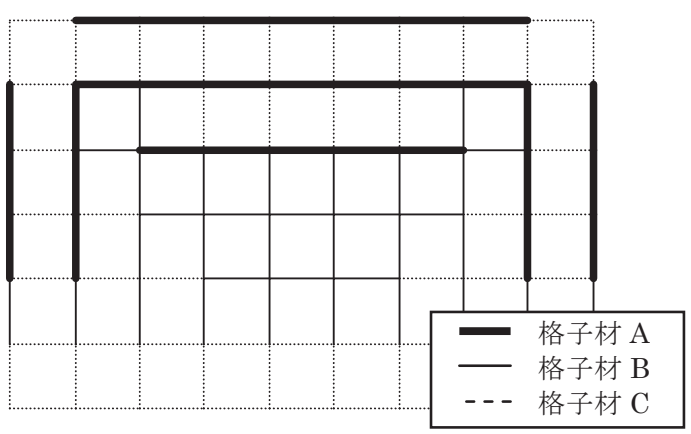

(a)上弦格子面
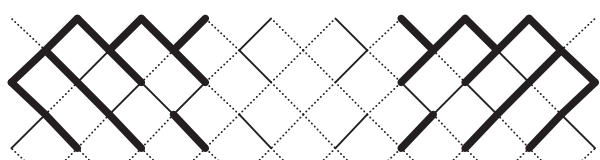

<

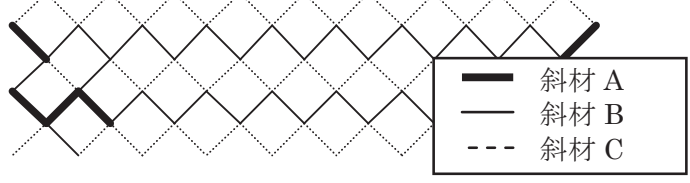

(b)斜材

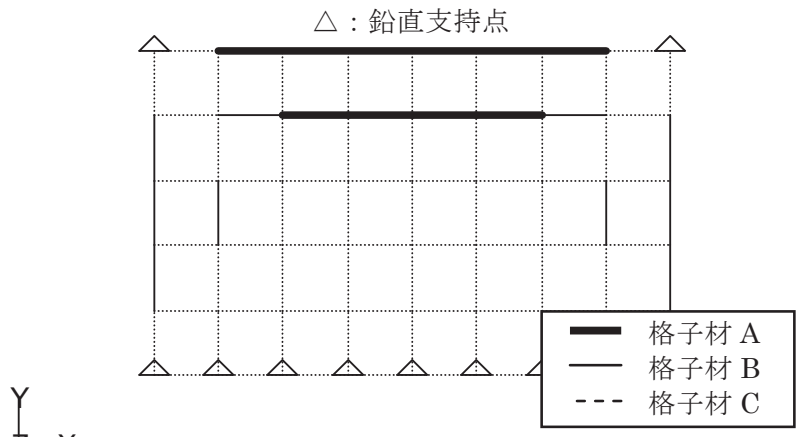

(c)下弦格子面

図 $17 n_{S}=6$ (格子材 3 , 斜材 3 )の場合の部材グルーピング

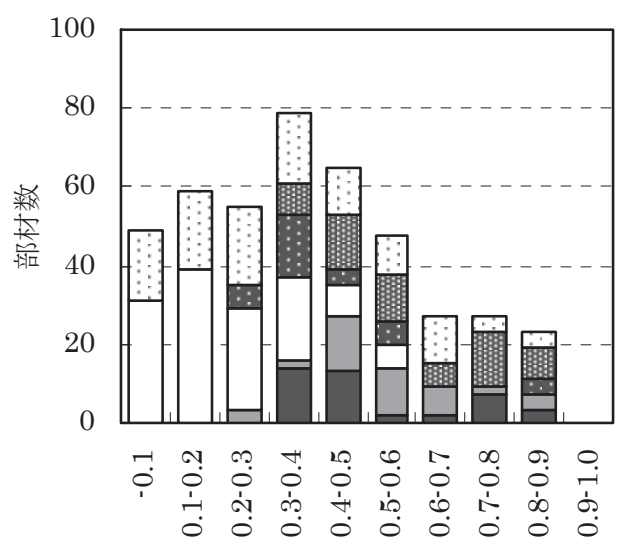

最適応力度比 $r^{*}$

$\begin{array}{lll}\square \text { 格子材 } \mathrm{A} & \square \text { 格子材 } \mathrm{B} & \square \text { 格子材 } \mathrm{C} \\ \text { 斜材 } \mathrm{A} & \text { 目斜材 } \mathrm{B} & \square \text { 斜材 } \mathrm{C}\end{array}$

図 18 格子材せい統一後の $r_{j}^{*}$ ヒストグラム

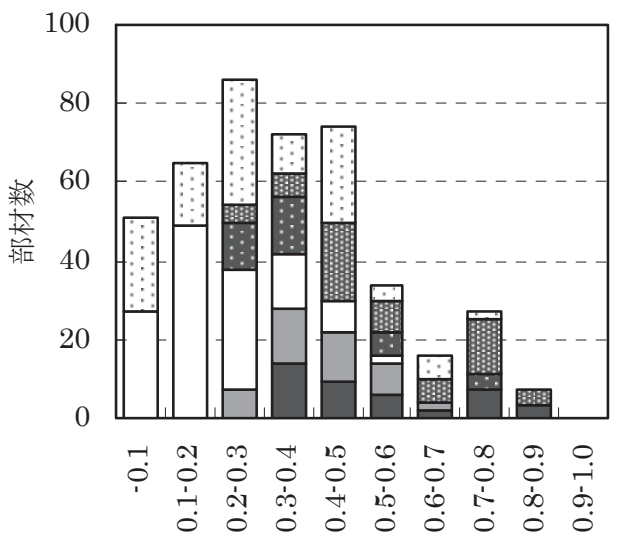

応力度比 $r_{j}^{*}$

$\begin{array}{lll}\text { 口格子材 } \mathrm{A} & \text { 口格子材 } \mathrm{B} & \text { 口格子材 } \mathrm{C} \\ \text { 圆斜材 } \mathrm{A} & \text { 国斜材 } \mathrm{B} & \text { 日斜材 } \mathrm{C}\end{array}$

図 19 JIS 規格断面を用いた場合の $r_{j}^{*}$ ヒストグラム

\begin{tabular}{|c|c|c|}
\hline \multicolumn{2}{|c|}{ グループ } & 最適断面寸法 \\
\hline \multirow[t]{3}{*}{ 格子材 } & A & H-300x300x10x15 \\
\hline & B & H-294x200x8x12 \\
\hline & $\mathrm{C}$ & $\mathrm{H}-300 \times 150 \times 6.5 \times 9$ \\
\hline \multirow[t]{3}{*}{ 斜材 } & A & $\bigcirc-267.4 \times 6.0$ \\
\hline & B & $-139.8 \times 4.5$ \\
\hline & $\mathrm{C}$ & $-114.3 \times 3.2$ \\
\hline
\end{tabular}

このように，4 章の設計支援システムを用いることで，構造設計 者の判断を交えながら総合的に満足できる設計解に極めて効率的に 到達することができる。

\section{6. 結論}

本論では，最適設計手法を用いた鋼構造物の部材断面決定問題に ついて，次の結論を得た。

1)外形寸法等，部材断面の代表寸法を連続な独立設計変数とし，残 りの寸法は規格断面リストを基に予め定める線形関数で与える手 法を提案した。これにより, 少ない設計変数で断面最適化問題を 
定式化しつつ，規格断面に近い最適解を得ることができる。

2) 与えられた同一断面部材グループの下で総部材コストを最小化す る断面最適化問題では，最適解において一部の部材が応力度比制 約をちょうど満足し，その他の部材には攵長性が残される。ある グループ内の部材を定められた応力度比(分割応力度比)を境に 2 つのグループに分け，あらためて最適化を行うことでコストはさ らに減少するが, その度合いは分割するグループや分割応力度比 の值に依存する。

3) 分割前の最適解における応力度比や部材コストを用いて, ある分 割グループ・分割応力度比に対応するコスト低減効果を簡便に予 測する指標を提案した。本指標が最も大きいグループ・応力度比 で分割し，あらためて最適化を実行することで，コストは効果的 に減少する。本指標は厳密に最適な分割を与えることを保証する ものではないが，その目的に照らして十分な精度を有しているこ とを例証した。

4) グループ分割・再最適化を重祃ることでコストは減少を続けるが, その度合いは徐々に鈍化することを例証した。過度なグループ分 割には実用上の意味がないばかりか，異種断面の接合が増えて製 作性・施工性等が低下寸ることになる。コストとグループ数の関 係は, 構造設計者が最終的な部材グループを決定する際の有力な 判断材料となる。

5) 上記 3) の指標を用いた自動グループ分割に加え, 特定部材のグル ープ間移動，グループ統合，断面間寸法制約の変更等を対話型で 行うことのできる設計支援システムを提案・構築した。本システ ムにより, 構造設計者は部材断面の選定過程における多くの試行 錯誤から解放されるだけでなく，専門的かつ総合的な判断を行う ための有益な情報を効果的に得ることができる。また，同システ ムを用いて立体トラス状架構の試設計を行い, 提案した手法の有 効性を示した。

\section{参考文献}

1) 沢田樹一郎, 中村雄治, 松尾彰 : 反復線形計画法による平面ラーメンの最 適設計 (その 1), 日本建築学会中国・九州支部研究報告 第 9 号, pp. 385-388, 1993

2)山川誠, 吉富信太, 上谷宏二 : 混合主成分分析による部材断面表現を用い た鋼構造骨組の最適設計法, 日本建築学会構造系論文集 第 583 号, pp. 77-83, 2004. 9

3) 吉富信太, 山川誠，上谷宏二 : 二段階緩和法に基づく鋼構造骨組の最適離 散断面選択法, 日本建築学会構造系論文集 第 586 号, pp. 95-100, 2004. 12

4) Koumousis, V. K., P. G. Georgiou,: Genetic Algorithms in Discrete Optimization of Steel Truss Roofs, Journal of Computing in Civil Engineering, Vol. 8, No. 3, pp. 309-325, 1994

5) 大崎純 : 遺伝的アルゴリズムに基づく不連続コスト関数を有する構造物の 最適設計法，日本建築学会構造系論文集 第 464 号, pp. 119-127, 1994.10

6) 松本慎也, 藤井大地, 藤谷義信 : はりせいを制約した鉄骨骨組構造の最小 重量設計, 日本建築学会中国支部研究報告書 第 22 巻, pp. 221-224, 1999

7) 澤田樹一郎, 松尾彰, 清水齐, 安井孝, 南波篤志 : 鉄骨製作コストの簡易 評価手法と鉄骨骨組の最適設計, 日本建築学会中国支部研究報告集 第 28 巻, pp. 221-224, 2005

8)佐々木尊一, 清水斉, 松尾彰, 澤田樹一郎, 南波篤志, 安井孝: 労務時間 資料に基づく鉄骨製作コストの簡易評価手法に関寸る研究，日本建築学会 中国支部研究報告集 第 30 巻, pp. 69-72, 2007

9) 田村尚土, 大森博司：多目的最適化法による鋼構造物の構造設計支援手法 の提案 その 1 許容応力度等設計における最適設計法, 日本建築学会構
造系論文集 第 73 巻 第 628 号, pp. 891-897, 2008.6

10) 上谷宏二：構造設計理論化のもくろみは、実務の壁を突破できるか?, 日 本建築学会近畿支部構造力学講究録 第 35 号, pp. 63-67, 2003

11) 五十子幸樹, 山川誠, 上谷宏二 : 数理的設計手法に基づく建築構造設計と 最適設計解感度分析, 日本建築学会構造系論文集 第 599 号, pp. 87-94, 2006. 1

12) Krishnamoorthy, C. S., Venkatesh, P. Prasanna, Sudarshan, R.: Object-Oriented Framework for Genetic Algorithms with Application to Space Truss Optimization, Journal of Computing in Civil Engineering, Vol. 16, No. 1, pp. 66-75, 2002

13) Togan, V., Daloglu, A. T.: An improved genetic algorithm with initial population strategy and self-adaptive member grouping, Computers \& Structures, Vol. 86, Issues 11-12, pp.1204-1218, 2008

14) Wallsa, R. and Elvin, A.: An algorithm for grouping members in a structure, Engineering Structures, Vol. 32, Issue 6, pp. 1760-1768, 2010 15）日本規格協会：JIS ハンドブック 2009 (2)鉄鋼 II , pp. 544-545， 2009

16) 日本建築学会 : 鋼構造設計規準 一許容応力度設計法一, 2005

17) Spellucci, P.: An SQP method for general nonlinear programs using only equality constrained subproblems, Mathematical Programming 82, pp.413-448, 1998 .

\section{注}

注 1)架構全体の力の流れを把握するには，軸力や曲げモーメントの影響度合 いを評価することが望ましいが，応力度比 $r_{j}$ を用いてこのような評価を行 うのは難しい。その理由を以下に述べる。

鋼構造設計規準 ${ }^{16)}$ の「6 章 組合せ応力」では，軸力と曲げモーメント による組合せ応力の応力度比検定式が軸力の正負に応じて 2 つずつ与えら れている。これらは異なる検討対象(引張縁と圧縮縁, もしくは降伏と座屈) に対応している。本論では，それら 2 つの応力度比を両部材端について算 出した上で, その最大值を部材の応力度比 $r_{j}$ としている(本論では部材中間 位置の応力度比は考慮していないが，採り入れることは難しくない)。また， 荷重ケースが複数ある場合は，それぞれの荷重ケースに対して上記のよう に応力度比の最大值を算出し, それらの最大值の中で最も大きな值をあら ためて $r_{j}$ としている。つまり， $r_{j}$ は部材によってそれを与える部材端や検 討対象, 荷重ケースが一般に異なるので, $r_{j}$ だけから架構全体の力の流れ を把握することはできない。また，応力度比は単に軸力の寄与分と曲げの 寄与分の和ではなく, 差をとる場合もあるため(例 : 引張力と曲げモーメン 卜を受ける部材の横座屈検定 $), r_{j}$ をそれぞれの寄与に分解することは困難 である。

なお，本論では部材せん断力に関する制約条件は設けていない。最適解 についてせん断力に関する検討を行い，せん断耐力が不足する部材には必 要な修正(ウェブ厚を上げる等)を施した上であらためて応力解析および断 面算定を行うものとする。修正を要する部材が多数ある場合は，非規格断 面の使用を前提として式(5)の寸法比を小さい值に設定して最適化をあら ためて行うことも考えられる。これらの判断は構造設計者に委衫らる。

注 2) 平面ラーメン架構の例題(3.3.2 節)では，各節点に鉄骨質量(構造質量)と 梁分布質量(非構造質量)の和に相当する集中質量を設けた上で, それらに鉛 直もしくは水平方向の一定加速度を乗じて節点荷重を算出している。鉄骨 質量ひいては節点荷重は従属設計変数であり，最適化が終了寸るまで值が 確定しない。そのため本論では節点荷重を加速度の值のみを用いて表現す ることとした。

注 3) 平面ラーメン架構の例題(3.3.2 節)において, 柱 $\left(S_{1}\right)$ は圧縮力と曲げモー メントを受ける部材, 梁 $\left(S_{2}\right)$ はほぼ曲げモーメントのみを受ける部材であ る。本例題では分割すべきグループとして $S_{1}$ が特定されたため，曲げ抵抗 型の骨組における提案手法の有効性が例証されたと言い切れない側面が残 る。だが, 図 9 を見ると $S_{2}$ についても $\widetilde{Q}$ は $Q$ を概补良好に近似しており, 少なくとも式(8)がモーメントが支配的な部材グループについても有効で あることは例証できている。

（2011年 1 月 7 日原稿受理， 2011年 3 月 4 日採用決定） 